\title{
A Study on Growth in Investment of Agro-Processing Units in Karnataka, India
}

\author{
K. Vasudeva Naik $^{1^{*}}$ and R.A. Yeledhalli ${ }^{2}$ \\ Department of Agribusiness Management, UAS, Dharwad, India \\ *Corresponding author
}

\section{Keywords}

Agro-processing, Industries,

Compound annual growth rate, Exponential growth, Recommendations

Article Info

Accepted:

22 July 2019

Available Online:

10 August 2019

\section{A B S T R A C T}

It was found that growth performance of agro-processing industries in Karnataka was unsatisfactory when compared with its other states. It is found that 48 per cent of the household expenditure in India is on food items and the demand for processed/convenience food is constantly increasing. With relatively cheaper labour, low cost of production, base for domestic and export markets could be set up. Processed products like packed polished wheat (atta) has widened the market, attracting multinationals like HALL and Pilsbury (a joint venture with Godrej). "Ready to eat" food and snacks are also slowly picking up. Agro-processing can be grouped as food processing and other agro processing like cotton, jute, etc. Currently, agro-processing industry is concentrated in the unorganized sector with low science and technology and little or no standardization and grading. Agro processing could be defined as set of techno-economic activities carried out for conservation and handling of agricultural produce and to make it usable as food, feed, fibre, fuel or industrial raw material. Compound annual growth rate was employed to arrive with the meaningful results. When compared to other industries in the third phase of 2011 to 2018, agro processing industries has got a considerable growth which signified the importance of agro processing industries. Therefore it has great scope for development in the state. Hence, it must be promoted extensively. Existing investment in this sector are found facing many problems which affect their operation.

\section{Introduction}

Indian agriculture has witnessed significant increase in capital formation in the postreform period compared to that in the prereform period. Since 2003, the Government has been injecting funds into the agricultural sector at an accelerated rate, which to an extent defies the notion of neglect of agriculture built up during the 1990s. During the $12^{\text {th }}$ Five-Year Plan (2012-2017), the capital formation was prolonged to public and private sectors with a concern about agricultural development and to improve the livelihood of farmers.

The States have increased investments in agriculture and infrastructure and have pushed market-driven policies that might have experienced a rapid growth in private farm investment and income (Seema Bathla, 2014). Agribusiness sector still dominates the India's economic scene by providing livelihood to majority of the population. In most of the 
developing countries including India, agricultural development is a precondition for economic development. Karnataka, India's seventh largest State in terms of geographical area $(1,91,791$ sq. $\mathrm{km})$ is home to 6.11 crore people (2011 Census) accounting for 5.05 per cent of India's population. The development of agriculture was expected to show a decline of 4.7 per cent in 2015-16 as against a growth of 1.6 per cent $2014-15$ and 130 lakh tonne expected during 2017-18 because of drought conditions in 136 taluks in kharif and 62 taluks in rabi. The industry sector (comprising mining and quarrying, manufacturing, construction and electricity, gas and water supply) is expected to grow by 4.5 per cent in 2015-16 as against a growth of 6.6 per cent during 2017-18 (Economic Survey of Karnataka, 2018).

The value of agricultural raw material is about 20.6 per cent of total industrial products and share of agriculture in the export market is more than 50 per cent. Thus development of agribusiness processing sectors influences the development of the whole economy. In this context, capital formation has taken place in different sectors of economy, viz., public and private sectors.

Capital formation will be divided into three stages viz., saving process, Fund available for investment and Acquisition of new capital assets. Agro processing could be defined as set of techno-economic activities carried out for conservation and handling of agricultural produce and to make it usable as food, feed, fibre, fuel or industrial raw material. Hence, the scope of the agro-processing industry encompasses all operations from the stage of harvest till the material reaches the end users in the desired form, packaging, quantity, quality and price. Inadequate attention to the agro-processing sector in the past put both the producer and the consumer at a disadvantage and it also hurt the economy of the country.

\section{Materials and Methods}

The study is done in Karnataka which is purely based on the extent of capital formation of agro processing units established in Karnataka. The study is based entirely on the secondary data which is collected from Directorate of Economics and Statistics, Bengaluru. The data is obtained for the study is from 1991 to 2018. In order to arrive with the meaningful results compound annual growth rate analysis was adopted for the study. Growth rate in agro processing industries in Karnataka was done. The linear, log-linear, exponential and power functions are some of the important functional forms employed to study the growth rates. Different functional forms were tried in the past for working out of growth rates in agroprocessing industries. Some of the important forms tried were the linear growth model ( $\mathrm{Y}=$ $a+b t)$, exponential function $\left(Y=a b^{t}\right)$ and quadratic function $\left(\mathrm{Y}=\mathrm{a}+\mathrm{bt}+\mathrm{ct}^{2}\right)$. However, it was found that the exponential form of the function $Y_{t}=a b^{t}$ is the better and most fitted one. In the present study, compound growth agro-processing industries in Karnataka as a whole were estimated by using the exponential growth function (Angles, 2001) of the form,

$Y_{t}=a b^{t} U_{t}$

Where,

$Y_{t}=$ Dependent variable for which growth rate was estimated (agro processing industries)

$\mathrm{a}=$ Intercept,

$\mathrm{b}=$ Regression coefficient

$\mathrm{t}=$ Year which takes values from 1, $2 \ldots \mathrm{n}$.

$\mathrm{U}_{\mathrm{t}}=$ Disturbance term in year' $\mathrm{t}$ '.

The equation (1) was transformed into loglinear and written as 
$\log \mathrm{Y}_{\mathrm{t}}=\log \mathrm{a}+\mathrm{t} \log \mathrm{b}+\log \mathrm{U}_{\mathrm{t}}$ (2)

Equation (2) was estimated by using Ordinary Least Square (OLS) technique.

The per cent compound growth rate (g) was derived using the relationship (3)

$g=(\operatorname{antilog} b-1) \times 100$

Where,

$\mathrm{g}=$ Estimated compound growth rate per annum in percentage.

$b=$ Antilog of $\log b$

The standard error of the growth rate was estimated and tested for its significance with student's 't' statistic.

\section{Results and Discussion}

The table 1 presents the Growth in investment in Industries and Agro processing units in Karnataka. It is evident from the Table that, the compound annual growth rate was found to be $12.13 \%$ per annum in case of industrial growth in Karnataka and 14.64 per cent per annum in case of growth of agro-processing industries. The findings also conveys that during the year 2008, the number of industries accounted was only $1,15,55,400$ where as in case of 2018, it was raised growth of $2,07,32,747$ number of industries. Similarly, in case of number of agro-processing industries in 2008 the agro-processing industries were 1,24,1467. In 2018 35,38,307 which was found around 9.26 per cent to the total growth in investment for agro-processing industries. However, the growth of investment in the year was only 0.35 per cent and 0.28 per cent for both total number of industries in Karnataka and total number of processing agro-industries after two decades it has been increased to the tune of growth per cent of 8.26 and 9.26 respectively. Similar results were obtained by (Varun Bashit and Rajrishi Singhal, 2008). Table 2 presents the growth in investment of the industries in the three different phases. In the first phase that is from 1991 to 2000 the growth of total industries was around 18.98 per cent with the time variable explaining to the tune of 44 percent. It can be observed from the table that growth rate in investment on agro-processing industries for the period with 16.63 per cent supported by the coefficient of determination to the extent of 63 percent. In the second phase of that is from the year 2001 to 2010, there was a positive growth rate of 14.80 per cent in the total industries in Karnataka. While in case of agro processing industries it was similar growth to the tune of 15.37 per cent. Coefficient of determination was up to 76 and 77 per cent respectively. In the third phase that is from 2011 to 2018, growth rate in industries were around 2.39 per cent which was supported by the time variable to the tune of 81 per cent. While in case of agro processing industries which was observed to be high with 3.12 per cent supported by the time variable to the extent of 74 per cent. The reason for this decline was that allocation of investment was given share for private investments also apart from public investments in the industrial and agroprocessing units.

The overall result signifies that there is a considerably high growth in investment for agro processing industries when compared to the other industries as a whole in the three phases.

In conclusion, this reveals that, there was not much competitive in the growth for investment. Agro-processing sector brings immense benefits to the people, to the economy and speed up industrialization process. However it has an insignificant place 
in Karnataka in relation to agricultural production. Therefore it has great scope for development in the state. Hence, it must be promoted extensively. Existing units in this sector are found facing many problems which affect their operation. In this context the recommendations made by the researcher can be of much help to the policy makers of the state who are engaged in framing agroprocessing industrial policies and also to the ago-processing entrepreneurs who are confronting many problems.

Table.1 Growth in investment in Industries and Agro processing units in Karnataka (1991-2018)

\begin{tabular}{|r|c|c|}
\hline Year & Investment of Industries in Karnataka & Investment of Agro-processing units \\
\hline $\mathbf{1 9 9 1}$ & $8,85,814$ & $1,06,020$ \\
\hline $\mathbf{1 9 9 2}$ & $11,21,630$ & $1,33,171$ \\
\hline $\mathbf{1 9 9 3}$ & $11,82,931$ & 172733 \\
\hline $\mathbf{1 9 9 4}$ & $15,59,299$ & $2,77,405$ \\
\hline $\mathbf{1 9 9 5}$ & $25,93,432$ & $1,52,952$ \\
\hline $\mathbf{1 9 9 6}$ & $31,1,499$ & $2,25,069$ \\
\hline $\mathbf{1 9 9 7}$ & $33,69,033$ & $1,89,011$ \\
\hline $\mathbf{1 9 9 8}$ & $34,98,299$ & $2,07,040$ \\
\hline $\mathbf{1 9 9 9}$ & $36,27,566$ & $5,94,262$ \\
\hline $\mathbf{2 0 0 0}$ & $35,68,474$ & $5,47,490$ \\
\hline $\mathbf{2 0 0 1}$ & $44,72,207$ & $6,05,208$ \\
\hline $\mathbf{2 0 0 2}$ & $49,24,073$ & $6,62,926$ \\
\hline $\mathbf{2 0 0 3}$ & $51,50,006$ & $7,20,644$ \\
\hline $\mathbf{2 0 0 4}$ & $53,75,939$ & $7,76,481$ \\
\hline $\mathbf{2 0 0 5}$ & $61,99,039$ & $9,23,017$ \\
\hline $\mathbf{2 0 0 6}$ & $70,45,334$ & $9,73,151$ \\
\hline $\mathbf{2 0 0 7}$ & $86,22,434$ & $12,38,092$ \\
\hline $\mathbf{2 0 0 8}$ & $11,55,5400$ & $12,41,467$ \\
\hline $\mathbf{2 0 0 9}$ & $1,26,90,000$ & $19,10,449$ \\
\hline $\mathbf{2 0 1 0}$ & $1,44,62,106$ & $22,98,270$ \\
\hline $\mathbf{2 0 1 1}$ & $1,84,59,633$ & $30,10,441$ \\
\hline $\mathbf{2 0 1 2}$ & $16,4,60,870$ & $26,89,050$ \\
\hline $\mathbf{2 0 1 3}$ & $1,74,60,251$ & $28,52,710$ \\
\hline $\mathbf{2 0 1 4}$ & $1,69,60,560$ & $27,79,516$ \\
\hline $\mathbf{2 0 1 5}$ & $1,72,10,406$ & $28,29,330$ \\
\hline $\mathbf{2 0 1 6}$ & $1,88,89,284$ & $31,80,032$ \\
\hline $\mathbf{2 0 1 7}$ & $1,98,11,015$ & $33,59,169$ \\
\hline $\mathbf{2 0 1 8}$ & $2,07,32,747$ & $35,38,307$ \\
\hline $\mathbf{C A G R}$ & $\mathbf{1 2 . 1 3} *$ & $\mathbf{1 4 . 6 4 * *}$ \\
\hline $\mathbf{R}$ & $\mathbf{0 . 6 2}$ & $\mathbf{0 . 7 7}$ \\
\hline $\mathbf{2}$ & & \\
\hline
\end{tabular}

*-Significant at 1 per cent level

**- Significant at 5 per cent level. 
Table. 2 Growth in investment in Industries and Agro-processing units in Karnataka for three different phases of development

\begin{tabular}{|c|c|c|c|}
\hline & & & (in percent) \\
\hline Particulars & $\begin{array}{c}\text { 1991-2000 } \\
\text { (Phase-I) }\end{array}$ & $\begin{array}{l}2001-2010 \\
\text { (Phase-II) }\end{array}$ & $\begin{array}{c}\text { 2011-2018 } \\
\text { (Phase-III) }\end{array}$ \\
\hline \multirow[t]{2}{*}{ Total Industries } & $18.98^{*}$ & 14.80 & $2.39 * *$ \\
\hline & 0.44 & 0.76 & 0.81 \\
\hline \multirow[t]{2}{*}{ Agro-processing units } & 16.63 & $15.37 *$ & $3.12 * *$ \\
\hline & 0.63 & 0.77 & 0.74 \\
\hline
\end{tabular}

*-Significant at 1 per cent level

**- Significant at 5 per cent level.

\section{References}

Jagadeeshamurthy, M.P., 1983, A comparative study of patterns of income, investment and savings in irrigated and non-irrigated farms - A case study in Hassan district Karnataka. M.Sc. (Agri.) Thesis, Uni. Agric. Sci, Bangalore.

Purohit, B.C. and Reddy, V.R., 1999, Capital formation in Indian agriculture: Issues and Concerns. Occasional Paper, National Bank for Agriculture and Rural Development, Mumbai, No. 9, p. 91.

Seema Bathla, 2014, Public and private capital formation and agricultural growth in India: State level analysis of inter-linkages during pre and postreform periods. Agric. Econ. Res. Rev., 27 (1): 19-36.

Swain, M., R. H. Patel, and Ojha M., 2011, Impacts of National Horticulture Mission Scheme in Rajasthan, Research Report No. 142, Agro-Economic Research Centre, S.P. University, V.V. Nagar, 125 - 132.

Varun Bisht and Rajrishi Singhal, 2008, Capital formation in India. Policy Research Unit, Dhanlaxmi Bank, Worli, Mumbai.

www.des.kar.nic.in

www.indiastats.com

\section{How to cite this article:}

Vasudeva Naik, K. and Yeledhalli, R.A. 2019. A Study on Growth in Investment of AgroProcessing Units in Karnataka, India. Int.J.Curr.Microbiol.App.Sci. 8(08): 2368-2372. doi: https://doi.org/10.20546/ijcmas.2019.808.275 